\title{
Analysis of poultry transit, notification systems and legislation in the state of Sergipe, 2008-2012
}

\author{
Análise do trânsito de aves, dos sistemas de notificação e da legislação \\ no estado de Sergipe entre 2008 e 2012
}

\author{
Vera Lucia Miñan de Oliveira', Fábio Raphael Pascoti Bruhn², Edna Lopes ${ }^{3}$, Eduardo Luiz Silva Costa', \\ Ana Paula Barros ${ }^{4}$, Christiane Maria Barcellos Magalhães da Rocha ${ }^{3}$, Joziana Muniz de Paiva Barçante ${ }^{5}$, \\ Ana Paula Peconick ${ }^{3}$, Stela Márcia Pereira ${ }^{5 *}$
}

\begin{abstract}
The purpose of this study was to assess the transit of poultry, as well as the inspection on the outbreak of diseases, by addressing the issues concerning the system of the National Program on Poultry Sanity and its legal resolutions. The data on the animal transportation and the occurrence of the diseases were collected from the official services. A legislation-based assessment was also carried out for the period from 2008 to 2012 in the state of Sergipe, Brazil. Results showed an intense transit of poultry in just about all towns of the state in the period under study, especially in chicken farms where less number of poultry is bred: from 5,000 to 15,000 . Besides, $64 \%$ of poultry transportation was found to be intermunicipal. The state of Sergipe has received poultry particularly from the states of Pernambuco $(49.87 \%)$, Bahia (20.85\%), Minas Gerais (5.94\%), Paraíba (5.16\%), and Goiás $(5.05 \%)$. The number of transit indicates an increase in transit over the years. In addition, three of six municipalities which saw these diseases (Estância, São Cristóvão and Itaporanga d'Ajuda) are responsible for a great part of the poultry transit. Results also showed that the majority of activities of the State Program on Poultry Sanity would be carried out in the municipalities where a larger poultry marketing flow takes place, thereby seeking to record a greater number of notifications on the diseases and, then, carry out the surveillance activities. Therefore, regarding the poultry transit, it is recommended to do a mapping of the risk regions for poultry diseases, as well as studies about the epidemiological characterization of the municipalities of the state of Sergipe.
\end{abstract}

KEYWORDS: chicken farm; animal sanitary defense; inspection; poultry sanity; National Program on Poultry Sanity.

\begin{abstract}
RESUMO: O objetivo deste estudo foi avaliar o trânsito de aves, sua fiscalização e o surgimento de enfermidades, abordando questóes referentes ao sistema do Programa Nacional de Sanidade Avícola e suas determinaçóes legais. Dessa forma, compilaram-se dados do serviço oficial sobre o trânsito dos animais e a ocorrência de doenças, realizando-se também uma avaliação da legislação vigente entre 2008 e 2012, no estado do Sergipe. Observou-se no período averiguado um intenso trânsito de aves em quase toda a totalidade dos municípios, principalmente entre granjas que alojam pequenas quantidades de aves (5.000 a 15.000), e 64\% do total do transporte de aves ocorreu entre municípios do Estado. Os estados fornecedores de aves para Sergipe foram sobretudo Pernambuco (49,87\%), Bahia (20,85\%), Minas Gerais (5,94\%), Paraíba (5,16\%) e Goiás $(5,05 \%)$. O número de guias de trânsito emitidas aponta um crescimento do trânsito ao longo dos anos. Verificaram-se que três municípios (Estância, São Cristóvão e Itaporanga d'Ajuda), dos seis acometidos por enfermidades, são aqueles responsáveis por grande parte do trânsito realizado. $\mathrm{O}$ estudo mostrou que para os municípios sergipanos, nos quais acontece maior fluxo de comercialização avícola, seriam indicadas mais das açóes do Programa Estadual de Sanidade Avícola, com a finalidade de registrar maior número de notificações de enfermidades e, consequentemente, exercer açóes de vigilância. Assim, quanto ao trânsito animal, recomendam-se a adoçáo de um mapeamento das regióes de risco sanitário para as enfermidades de aves e a realização de estudos sobre a caracterização epidemiológica dos municípios de Sergipe.
\end{abstract}

PALAVRAS-CHAVE: granjas; defesa sanitária animal; fiscalização; sanidade avícola; Programa Nacional de Sanidade Avícola.

'Ministério da Agricultura, Pecuária e Abastecimento (Mapa) - Sergipe, Brazil.

²Departamento de Veterinária Preventiva (DVP); Universidade Federal de Pelotas (UFPel) - Pelotas (RS), Brazil.

${ }^{3}$ Departamento de Medicina Veterinária (DMV); Universidade Federal de Lavras (UFLA) - Lavras (MG), Brazil.

${ }^{4}$ Coordenadoria de Defesa Animal (Codea), Empresa de Desenvolvimento Agropecuário de Sergipe (Emdagro) - Nossa Senhora do Socorro (SE), Brazil.

${ }^{5}$ Departamento de Ciências da Saúde (DAS); UFLA - Lavras (MG), Brazil.

*Corresponding author: stelapereira@dsa.ufla.br

Received on: 03/25/2014. Accepted on: 03/30/2016 


\section{INTRODUCTION}

Brazil was known as the largest chicken meat exporting country in 2012, with 3,943 million metric tons exported, thus corresponding to about $40 \%$ of the total amount of chicken meat exported in the world (UbABEF, 2012). Therefore, based on this prominent role on the global scene, Brazil should follow international standards to preserve its presence in the chicken meat production and marketing processes.

To attend an increasingly demanding consumer and a competitive market, the country should be aware of the new demands and aspirations of an importing market worried about animal welfare and food innocuousness. The law obeyed in animal production process is often based on international standards, and not domestic framing (SiLva et al., 2009), such as the one related to practices for animal welfare. This is the reason why standards, regulations and legislation used in the country are constantly updated.

The Animal Sanitary Defense aims at the prevention, diseases control, public health, assessment of risk of emergence and spread of diseases, food security, and animal welfare. According to the World Organization for Animal Health (OIE), veterinary services are considered to be a global public good. Then, for the great animal health, the Defense Veterinary Service should be well structured and qualified to perform actions for detection, control, and eradication of animal diseases.

In this context, the assessment of poultry transport process is found to be important, concurrently with the maintenance of an effective notification system for the outbreak of diseases, and continuous monitoring, for which data related to poultry facilities are often updated. So, preventive, combat, and control measures can be effectively prioritized in an outbreak situation, preventing the diseases spread (DENT et al., 2011; VAn SteEnwinkel et al., 2011).

Two technical auditing of the Brazilian Ministry of Agriculture, Livestock and Food Supply (Mapa) were carried out in the state of Sergipe in 2009 and 2010, seeking to assess the State Defense System related to the Program of Poultry Sanity (BrasiL, 2006b). The following items were observed and scored: physical structures, information technology, number of veterinary physicians, notification of diseases, state law enforcement, traffic control, and sanitary education. Among these parameters, traffic control, legislation and notification of diseases were found to be the most defective and required improvements.

This study was carried out with the aim to assess the poultry transport and link it to the outbreak of diseases in the species. Moreover, we did an assessment of the Defense Veterinary Services of Agricultural Development Company of the State of Sergipe (Emdagro), with a focus on the National Program of Poultry Sanity (PNSA), and with the target to help in the improvement of the services and the grading assigned by the Mapa.

\section{MATERIALS AND METHODS}

At $21,092 \mathrm{~km}^{2}$ and 75 municipalities, the Defense Veterinary Service activities are performed in the state of Sergipe based on the power delegation done by means of an agreement established with the Emdagro and the Mapa.

The Agricultural Protection System (Sideagro) was used to obtain the data concerning the poultry transit for the period from 2008 to 2012, and consisted of 58 monthly reports of checkpoints. After September 2012, the Agricultural Integration System (Siapec) was developed instead, providing a more modernized version which can generate six reports more than the old version. These platforms also provided detailed information about the property registration, the number of animals in transit, vaccination information, the entrance and exit of animals in the property, as well as general information about animal transport. In addition, 206 reports about the poultry transit were collected. These reports were written by veterinary physicians accredited by Mapa for the issue of animal transit permits, and consisted of data on the entry and exit of animals, the movement of animals in the state, as well as the interstate transportation.

Analyses on the notification of diseases, epidemiological information, and entries found in the Surveillance System were carried out. Monthly information about poultry diseases which were recorded in 96 notification forms, issued by nine technicians and accredited by the Mapa and the persons in-charge of chicken farms in the state of Sergipe, was analyzed. Moreover, 60 forms about epidemiological information from official services, as well as data entries recorded in Continental Surveillance System of Panaftosa (Sivcont), for the period from January 2008 to November 2012, were also analyzed.

\section{RESULTS AND DISCUSSION}

The Defense Veterinary Service of the state of Sergipe, Brazil, consists of the headquarters responsible for coordinating animal defense services, a laboratory, 22 local veterinary units (LVUs), and 70 community support offices. The Emdagro staff consists of 33 official veterinary physicians and 77 sanitary inspectors who assist in defense activities.

The LVU is the most important division of the animal defense system, and it is responsible for the notification of diseases as well as animal first aids. Analyses of the notification of diseases and the risk of emergencies, besides the spread of diseases, are also carried out in this unit (SERRÃo et al., 1991).

All Emdagro veterinary care offices are provided with communication and computer equipments, on transportation and professionals on animal care services related to animal sanitary defense, as outlined in Mapa Decree No. 50/1997, regarding health service structures (BRASIL, 1997). 
There are four hatcheries and two matrices in Sergipe, which are used to lodge about five million one-day-old chicks for a month and, then, supply them mainly to the domestic market. The poultry breeding establishments are located in the municipalities of Itaporanga D’Ajuda, São Cristóvão, Estância and Maruim. They deliver one-day-old chicks in all towns of the state, as well as in other states, for rearing and fattening. However, there is no establishment responsible for the delivering of poultry genetic material in Sergipe.

The majority of chicken farms of the state of Sergipe operate under the integration system, which consists in delivering a given quantity of one-day-old chicks from hatcheries to chicken farms, where they are reared until the slaughter age and, then, sent to storage refrigerators. The integrator chicken farm is responsible for supplying ration, medicines and veterinary care. The integrator is responsible for poultry management and marketing of poultry litter. Beyond it, other chicken farms operate independently and they acquire fertile eggs and one-day-old chicks from other Brazilian states.

Studies about poultry transportation, Brazilian legislation, epidemiological and sanitary surveillance, as well as their relation to animal welfare, are scarce in the Brazilian literature. However, recent and relevant publications about poultry transportation have been found from international journals. Thus, achievements regarding the following parameters are highlighted in this paper, seeking to prevent potential stressful variables able to increase mortality and morbidity and reduce production efficiency and animal welfare: behavioral, physiological and physical variables (Nijdam et al., 2004; Cheng; JefFerson, 2008); vehicle engineering and design for long-distance land transportation (Mitchell; KetTlewell, 2008); long-distance transportation and food security (Riвò et al., 2008); fasting for transportation and chicken meat quality (DelezIE et al., 2007); seasons of the year and quality of facilities on arrival (VECEREK et al., 2006); assessment of standards about the topic (HARTUNG, 2006).

The animal transit and livestock farming are found to be the primary events for dissemination of animal diseases. So, an effective system of information and surveillance is a tool that should be used in the diseases control and eradication (Carvalho et al., 2012). In fact, the poultry transit is not static, but dynamic, and shows variations in terms of flow, target and purpose. Accredited veterinary physicians write reports about the movement of animals in the state, as well as interstate transportation. The monitoring of entry and exit of animals in checkpoints, however, is Official Veterinarian Services responsibility. Therefore, the Agricultural Integration System provides a more modernized platform in monitoring poultry movements, mainly from and to other Brazilian states. Auditing reports show that official veterinary physicians should consider the poultry transit as a risk factor for the outbreak of diseases in municipalities under their jurisdiction. This would reduce the risk and, consequently, the occurrence and spread of diseases.

The poultry farming of the state of Sergipe is responsible for supplying broiler chicken to the local market. Then, 64\% of poultry transportation recorded from 2008 to 2012 was found to be intermunicipal (Table 1).

Sergipe has received poultry particularly from the states of Pernambuco (49.87\%), Bahia (20.85\%), Minas Gerais (5.94\%), Paraíba (5.16\%), and Goiás (5.05\%). The remaining percentage (13.14\%) corresponds to the movement of poultry from other Brazilian states to Sergipe. Regarding destination, poultry was delivered from Sergipe to Pernambuco (63\%), followed by Bahia (26.3\%) (Table 2).

The majority of poultry in transit in the state of Sergipe, recorded from 2008 to 2012, was for fattening (65\%), followed by poultry for slaughter $(33.9 \%)$, and poultry for reproduction $(0.94 \%)$, i.e., fertile eggs and one-day-old matrices for broiler chicken and, then, for agricultural and livestock events (0.12\%) (Table 3).

There is an intense poultry transit in just about all municipalities of the state of Sergipe in the period under study, especially in chicken farming, in which some quantity of poultry, 10,000-15,000, are bred; and even lesser quantity, around 5,000, when the poultry comes from family farms. Besides, we found out that there is an intense marketing of live poultry in trade fairs and municipal markets. However, there is no epidemiological information addressing about the risk of this type of trade. This information would be useful to support professionals working in the poultry sanity area, i.e., in the municipalities with greater flow of poultry transit.

Table 1. Poultry transit recorded in the state of Sergipe, Brazil, from 2008 to 2012.

\begin{tabular}{|c|c|c|c|c|c|c|c|c|c|c|c|c|}
\hline \multirow{2}{*}{ Transit } & \multicolumn{12}{|c|}{ Number of poultry } \\
\hline & 2008 & $\%$ & 2009 & $\%$ & 2010 & $\%$ & 2011 & $\%$ & $2012^{*}$ & $\%$ & Total & $\%$ \\
\hline Municipal & $6,164,501$ & 17.1 & $2,062,336$ & 6.2 & 872,846 & 4.8 & 908,467 & 5.6 & $1,631,118$ & 6.1 & $11,639,268$ & 9.0 \\
\hline $\begin{array}{l}\text { Of the } \\
\text { state }\end{array}$ & $18,826,083$ & 52.3 & $25,834,197$ & 77.5 & $12,088,482$ & 66.7 & $9,536,974$ & 58.7 & $16,484,882$ & 61.6 & $82,770,618$ & 64.0 \\
\hline Entry & $4,856,191$ & 13.5 & $1,134,900$ & 3.4 & $1,972,084$ & 10.9 & $3,090,358$ & 19.0 & $3,452,142$ & 12.9 & $13,370,775$ & 10.3 \\
\hline Exit & $6,164,501$ & 17.1 & $4,301,543$ & 12.9 & $3,192,084$ & 17.6 & $2,704,561$ & 16.7 & $5,199,343$ & 19.4 & $21,562,032$ & 16.7 \\
\hline Total & $36,011,276$ & 100 & $33,332,976$ & 100 & $18,125,496$ & 100 & $16,240,360$ & 100 & $26,767,485$ & 100 & $129,342,693$ & 100 \\
\hline
\end{tabular}

*Data recorded by the month of November. 
The poultry activity in Sergipe assumes a distinguishing characteristic when compared to the existing production systems in other Brazilian federative units due to the lesser surface area of the state $\left(21,091 \mathrm{~km}^{2}\right)$ and the proximity among municipalities. There are hardly any integration systems in the state, for example, in South and Midwest Brazil, where large companies are responsible for providing young poultry to the integrator, which rear them until the slaughter age and, then, they are slaughtered at the same slaughterhouse. In Sergipe, trucks are used to transport poultry and, then, for marketing in less quantities.

Table 4 shows records about the poultry transit in the municipalities of the state of Sergipe, for the period from 2008 to 2012. These results present that $71 \%$ of poultry transit occurs in the following towns: Aracaju (17.9\%), Simão Dias (15.92\%), São Cristóvão (11.7\%), Itaporanga d'Ajuda (9.07\%), Lagarto (8.69\%), Santo Amaro das Brotas (4.04\%), and Estância (3.97\%). These results are found to be relevant in these seven municipalities, because they are also concentrated in $71 \%$ of notification of diseases, suggesting a possible risk of association between poultry transit and high incidence of diseases.
There are no initiatives about sanitary education aiming to increase the records of suspicions in the state. These data would improve the quality of surveillance activities. Besides, a mapping of sanitary risk regions for poultry diseases has not been done yet, even studies about epidemiological characterization regarding poultry transit.

Due to the lack of epidemiological information, results obtained in this study are found to be important as they suggest the need for better sanitary care and compliance of the legislation, seeking to reduce the possibility of occurrence of poultry diseases in the state, especially in seven municipalities described before, in which it suggests a potential sanitary risk.

According to dynamic characteristics of the poultry transit, it is possible to suggest the need of veterinary physicians to work for the National Program of Poultry Sanity or the reactivation of the emergency response team to perform surveillance activities, in order to increase notifications of diseases, which are found to be essential for the epidemiological surveillance process of diseases.

Table 2. Destination of poultry from the state of Sergipe, Brazil, 2008-2012.

\begin{tabular}{|c|c|c|c|c|c|c|}
\hline UF & 2008 & 2009 & 2010 & 2011 & $2012^{*}$ & Total (\%) \\
\hline BA & 956,712 & 734,980 & 207,825 & 351,244 & $1,227,605$ & $3,478,366(20.8)$ \\
\hline$A L$ & 307,750 & 46,125 & 825 & 164,444 & - & $519,144(3.1)$ \\
\hline PE & $1,819,850$ & $2,088,550$ & $1,179,318$ & $2,465,808$ & 766,268 & $8,319,794$ (49.9) \\
\hline CE & 35,700 & 35,700 & 26,000 & 6 & - & $97,406(0.6)$ \\
\hline MG & 503,000 & 313,806 & 74,436 & 71,046 & 28,936 & $991,224(5.9)$ \\
\hline ES & 94,286 & 6,832 & 6,832 & 8,602 & - & $116,552(0.7)$ \\
\hline SP & 204,740 & 260,387 & 59,423 & 7,008 & 33,759 & $565,317(3.4)$ \\
\hline SC & 603,004 & - & - & - & - & $603,004(3.6)$ \\
\hline GO & 182,560 & 367,208 & 146,998 & - & 144,996 & $841,762(5.0)$ \\
\hline MS & 5,763 & - & - & 22,200 & - & $27,963(0.2)$ \\
\hline DF & 142,830 & 28,032 & & - & 7,500 & $178,362(1.1)$ \\
\hline PB & - & 416,523 & 189,623 & - & 253,900 & $860,046(5.2)$ \\
\hline MA & - & - & 3,400 & - & - & $3,400(0.0)$ \\
\hline MT & - & 3,400 & 77,404 & - & - & $80,804(0.5)$ \\
\hline Total & $4,856,195$ & $4,301,543$ & $1,972,084$ & $3,090,358$ & $2,464,976$ & $16,683,144$ \\
\hline
\end{tabular}

UF: Federative Units; BA: Bahia; AL: Alagoas; PE: Pernambuco; CE: Ceará; MG: Minas Gerais; ES: Espírito Santo; SP: São Paulo; SC: Santa Catarina; GO: Goiás; MS: Mato Grosso do Sul; DF: Distrito Federal; PB: Paraíba; MA: Maranhão; MT: Mato Grosso; *Data recorded by the month of November.

Table 3. Poultry transit clustered according to the purpose, Sergipe, Brazil, 2008-2012.

\begin{tabular}{lcccccc} 
Purpose & \multicolumn{5}{c}{ Number of poultry in transit } \\
\cline { 2 - 7 } & $\mathbf{2 0 0 8}$ & $\mathbf{2 0 0 9}$ & $\mathbf{2 0 1 0}$ & $\mathbf{2 0 1 1}$ & $\mathbf{2 0 1 2 ^ { * }}$ & Total (\%) \\
\hline Slaughtering & $11,226,500$ & $11,614,018$ & $6,023,923$ & $5,734,660$ & $9,308,499$ & $43,907,600(33.9)$ \\
\hline Fattening & $24,372,208$ & $20,323,157$ & $11,691,685$ & $10,413,000$ & $17,263,074$ & $84,063,124(65.0)$ \\
\hline Reproduction & 412,568 & 260,901 & 255,695 & 92,700 & 191,807 & $1,213,671(0.9)$ \\
\hline Event & 0 & 0 & 154,193 & 0 & 4,105 & $158,298(0.1)$ \\
\hline Total & $36,011,276$ & $32,198,076$ & $18,125,496$ & $16,240,360$ & $26,767,485$ & $129,342,693$ \\
\hline
\end{tabular}

*Data recorded by the month of November. 
The poultry transit is regulated and inspected by means of animal transit permits, which are lawfully regulated by the Normative Instruction of July 18, 2006 (BrasiL, 2006c). Regarding the interstate transportation, the Emdagro also issues transit permits for other animal species such as poultry and small poultry farms; in both situations there is no technician for assistance. The Official Animal Defense Service is responsible for monitoring the entry and exit of animals in checkpoints. The transit permits issued by accredited veterinary physicians, however they are registered in the Agricultural Integration System (Siapec), seeking to establish a database, which will be used in implementing further animal defense strategies.

Table 5 and Chart 1 illustrate the number of transit permits issued for poultry in the period under study. These data

Table 4. Poultry transit in the municipalities of the state of Sergipe, Brazil, 2008-2012.

\begin{tabular}{|c|c|c|c|c|c|c|}
\hline \multirow{2}{*}{ Municipality } & \multicolumn{6}{|c|}{ Number of poultry in transit } \\
\hline & 2008 & 2009 & 2010 & 2011 & $2012 *$ & Total \\
\hline Aquidabã & - & 970,000 & - & 354,669 & 519,390 & $1,844,059$ \\
\hline Aracaju & 410,450 & $5,131,196$ & $2,669,523$ & $2,680,232$ & $2,356,408$ & $13,247,809$ \\
\hline Areia Branca & - & - & 306,279 & - & 30,669 & 336,948 \\
\hline Canindé de São Francisco & 233,024 & 541,162 & - & - & - & 774,186 \\
\hline Capela & 333,751 & - & 561,555 & 463,595 & 209,559 & $1,568,460$ \\
\hline Cedro de São João & - & & 250,370 & - & 70,203 & 320,573 \\
\hline Estância & 513,819 & 901,289 & 498,467 & 438,438 & 589,848 & $2,941,861$ \\
\hline Itabaiana & - & - & 450,456 & 513,726 & 621,990 & $1,586,172$ \\
\hline Itabaianinha & - & - & 274,821 & - & 202,170 & 476,991 \\
\hline Itaporanga D’Ajuda & $1,468,070$ & $1,578,076$ & $1,420,035$ & $1,432,845$ & 815,764 & $6,714,790$ \\
\hline Lagarto & 864,277 & $1,470,513$ & $1,580,244$ & $1,588,898$ & 927,330 & $6,431,262$ \\
\hline Maruim & 346,729 & 370,030 & 368,306 & 482,510 & 434,115 & $2,001,690$ \\
\hline Nossa Senhora do Socorro & 525,153 & 681,986 & 533,132 & 300,880 & - & $2,041,151$ \\
\hline Nossa Senhora da Glória & 590,832 & - & - & - & 49,900 & 640,732 \\
\hline Nossa Senhora das Dores & 865,279 & 483,292 & 441,334 & 454,327 & 796,349 & $3,040,581$ \\
\hline Pacatuba & - & - & - & 402,280 & 219,860 & 622,140 \\
\hline Propriá & 336,492 & 457,820 & 408,352 & 746,405 & 374,265 & $2,323,334$ \\
\hline Rosário do Catete & - & - & - & - & 283,696 & 283,696 \\
\hline Salgado & 357,570 & 689,251 & 667,417 & 368,050 & 606,815 & $2,689,103$ \\
\hline Santa Luzia do Itanhy & - & - & - & 338,682 & 48,760 & 387,442 \\
\hline Santo Amaro das Brotas & 307,795 & 498,316 & 416,713 & $2,031,618$ & 2,400 & $3,256,842$ \\
\hline São Cristóvão & $1,304,114$ & $2,384,051$ & $2,107,704$ & 414,813 & $2,503,476$ & $8,714,158$ \\
\hline Simão Dias & $1,050,875$ & $1,689,560$ & $2,225,340$ & $2,977,973$ & $3,840,616$ & $11,784,364$ \\
\hline Total & $9,508,230$ & $17,846,542$ & $15,180,048$ & $15,989,941$ & $15,503,583$ & $74,028,344$ \\
\hline
\end{tabular}

*Data recorded by the month of November.

Table 5. Number of poultry transit permits issued in the state of Sergipe, 2008-2012.

\begin{tabular}{lcccccc} 
Purpose & \multicolumn{5}{c}{ Number of transit permits } \\
\cline { 2 - 7 } & $\mathbf{2 0 0 8}$ & $\mathbf{2 0 0 9}$ & $\mathbf{2 0 1 0}$ & $\mathbf{2 0 1 1}$ & $\mathbf{2 0 1 2 ^ { * }}$ & Total \\
\hline Municipal transit & 628 & 1,018 & 934 & 1,009 & 1,627 & 5,216 \\
\hline Intrastate transportation & 8,661 & 15,225 & 14,324 & 10,082 & 20,770 & 69,062 \\
\hline Entry in the state & 969 & 1,294 & 653 & 370 & 656 & 3,942 \\
\hline Exit from the state & 709 & 583 & 357 & 345 & 444 & 2,438 \\
\hline Total & 10,967 & 18,120 & 16,268 & 11,806 & 23,497 & 80,658 \\
\hline
\end{tabular}

*Data recorded by the month of November. 
show an increasing for poultry transit over the years, especially for transportation in the state, which represents $85.6 \%$ of the total of transit permits issued during that period.

According to Brazilian legislation in use, the first normative legal act on the structuring of the animal health services was the Decree No. 50/1997 (BrasIL, 1997), which classifies criteria related to the veterinary attention for the official service. This decree also establishes risks associated with foot-and-mouth disease in Brazilian federative units. Moreover, the Law No. 9,712/1998 (BrasiL, 1998) delegates power for animal sanitary defense. This law was lawfully outlined in the Decree No. 5,741 of March 2006, regarding the organization of the Unified System for Veterinary Attention (BrasiL, 2006a).

With the evolution of audit programs of animal defense services, the assessment of services was adopted by the PNSA, instituted in the Decree No. 193 of September 19, 1994. Activities related to control and prevention of avian influenza and Newcastle

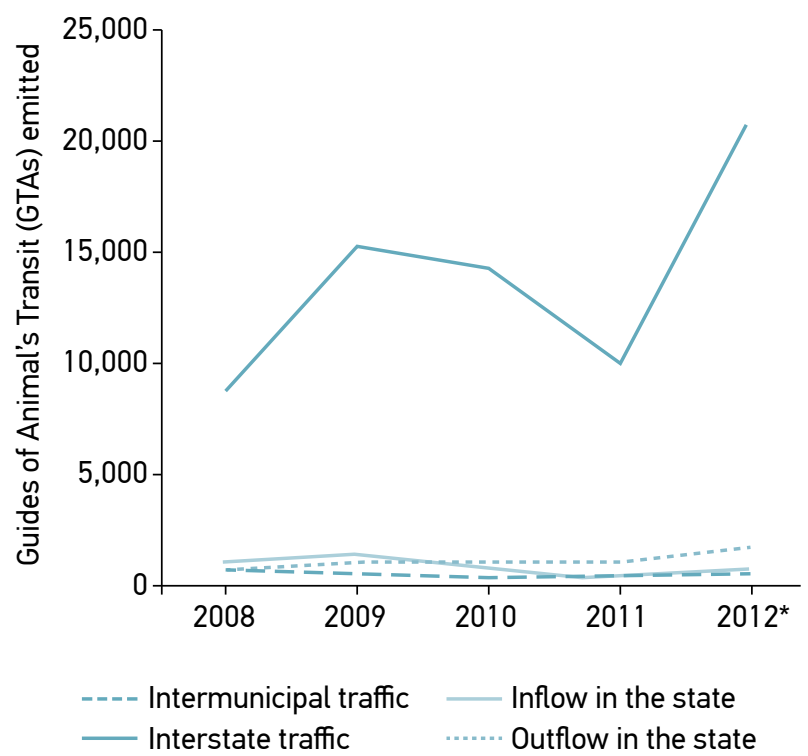

*Data recorded by the month of November.

Chart 1. Number of poultry transit permits issued in the state of Sergipe, 2008-2012. disease were lawfully outlined in the Normative Instruction No. 17 of April 7, 2006 (BrasiL, 1994; BrasiL, 2006b).

Regarding the legislation used by the state agency on poultry sanity, the legal support should be in accordance with federal legislation. However, the state legislation should use a more restrictive legal criterion. Therefore, the existing state legislation does not comprise punitive actions for those who do not accomplish requirements of the poultry sanitary program, although recent efforts were made for the development of an instrument that could regulate sanitary care necessary for good poultry-breeding practices. This issue can lead to serious prejudices to the poultry-breeding program of the state.

Regarding notifications of poultry diseases, an access was found in the following municipalities: Estância, São Cristóvão, Japoatã, Itaporanga d'Ajuda, Pirambu and Barra dos Coqueiros. Table 6 describes diseases such as mycoplasmosis and sudden death with no identified cause. Besides, it also presents salmonellosis, mortality of migratory birds and poultry mortality greater than $10 \%$ of the flock.

Table 6 also shows that three of six municipalities accessed with diseases (Estância, São Cristóvão and Itaporanga d'Ajuda) are responsible for great part of the poultry transit in the state, pointing out the importance of the poultry transportation in the occurrence and spread of diseases. In case of notification of diseases, either the official service or the accredited veterinary physicians send information contained in proper forms. However, diseases characterized by nervous symptoms should be notified to the official veterinarian service within 24 hours, so that they will be reported in time to the Epidemiology Coordination of the Mapa to accomplish the objective of the Continental Vigilance System (in Portuguese, Sistema de Vigilância Continental — SIVCONT). In addition, other diseases such as sudden death, mycoplasmosis and salmonellosis should also be entered in the SIVCONT, a system that provides a clear view about the occurrence of diseases and actions related to animal defense.

Therefore, we found that the diseases notification system is not up to the mark as it does not include information about poultry. Besides, the majority of notifications on diseases were

Table 6. Notifications of poultry diseases in municipalities of Sergipe, 2008-2012.

\begin{tabular}{lccc}
\hline Month/Year & Municipality & Disease & Origin \\
\hline March/2008 & Estância & Mycoplasmosis & Certification \\
\hline May/2008 & Estância & Mycoplasmosis & Certification \\
\hline July/2008 & São Cristóvão & Sudden death & $\begin{array}{c}\text { Notification of an accredited } \\
\text { veterinary physician }\end{array}$ \\
\hline 2008 and 2009 & Japoatã & Sudden death & Denunciation \\
\hline September/2010 & $\begin{array}{c}\text { Pirambu e Barra } \\
\text { dos Coqueiros }\end{array}$ & $\begin{array}{c}\text { Newcastle disease, low } \\
\text { pathogenicity for wild birds }\end{array}$ & Denunciation \\
\hline July/2011 & Itaporanga d'Ajuda & Mycoplasmosis & Certification \\
\hline December/2011 & Itaporanga d'Ajuda & Mycoplasmosis & Certification \\
\hline
\end{tabular}


issued by the veterinary physicians accredited by the Mapa, which act as technicians responsible for the poultry farms, or were obtained as the result of the official monitoring of the certification.

It is important to check whether Brazilian federative units abide or not to the Normative Instruction No. 44/2001 of the Mapa (BrasiL, 2001), which outlines the need for a certification for interstate poultry transportation free of salmonellosis and mycoplasmosis. Thus, it is possible to reduce the risk of introduction of mycoplasma and salmonella in the flock of the state, if not all breeding establishments are registered in the Mapa, and if not all of them fall under the monitoring against diseases listed in the PNSA database.

The certification process consists of the periodic collection of samples (cloacal swab, pipped eggs and of drag) from the matrices of the official service. Then, this material is sent to a laboratory accredited by the Mapa, in order to certify whether the poultry establishment is free or not for mycoplasma controlled, and whether it is free or not for salmonella (BRASIL, 2003). However, in this study, we found out the importance of official certification for the notification of diseases, which allows the carrying out of lawful actions of the agency for animal sanitary defense and a consequent improved diseases control. Nonetheless, the official veterinary service did not collect samples during notifications of diseases, as recommended by the National Program of Poultry Sanity.

The majority of monthly notifications, as well as those recorded in epidemiological forms for the period from 2008 to $2012(76.3 \%)$, resulted from reports and information about poultry mortality issued by veterinary physicians accredited by the Mapa, not by the official service. Without taking into consideration the poultry transit, these physicians are responsible for the notification of diseases listed in the PNSA, poultry mortality greater than $10 \%$ of the flock, sudden death with nervous symptoms, as well as for filling sanitary bulletins at the slaughter time in slaughterhouses which possess veterinary inspection services (BrasIL, 2006b).

There was only one denunciation from the Brazilian Institute of Environment and Renewable Natural Resources (Ibama) in the period under study, which approached the mortality of migratory birds in the municipalities of Pirambu and Barra dos Coqueiros. Samples resulting from this monitoring process were processed at the National Agricultural Laboratory (Lanagro) of the Ministry of Agriculture, in Campinas (SP). The Newcastle disease, however, occurred in wild birds, not in poultry farms, in which it would be necessary to apply control measures based on poultry euthanasia and transit discontinuation, due to the great danger of occurrence of viral replication and, thereby, increase its pathogenicity (BRASIL, 2002).

For the accomplishment of animal defense activities, the official veterinary physicians should have complete knowledge about the structure of municipalities under their jurisdiction. The parameters considered here are the following: number of slaughterhouses, registration of farms, location of trade fairs and animal agglomerations, registration of local authorities, and georeferencing of farms under risk of outbreak of diseases. In addition, they must control the entry and exit of animals, breeding systems, and animals marketing processes in the area. This means that the veterinary physician responsible for a LVU should know about the epidemiological characterization of his municipality (Astudillo, 1991). This knowledge makes possible a greater responsiveness to problems and a better use of resources in the development of activities about animal sanitary defense. Therefore, a good surveillance system associated with the inspection of poultry transit is found to be important (Astudillo, 1991).

\section{CONCLUSION}

Sanitary education activities are needed in the municipalities in which the greater poultry marketing flow occurs, seeking to record greater number of probable diseases and, then, allowing the sanitary defense agency to carry out surveillance activities. Regarding the poultry transit, therefore, the mapping of sanitary risk regions for poultry diseases and studies about epidemiological characterization of the municipalities of the state of Sergipe are found to be necessary.

\section{ACKNOWLEDGMENTS}

This study was funded by the Livestock Defense Secretary (SDA) of Mapa/Brazilian National Council for Scientific and Technological Development (CNPq). The specialization course at the Postgraduate Lato Sensu level was done in Animal Sanitary Defense (DEF), at Program of Continuous Training in Animal Sanitary Defense (Prodesa), of Universidade Federal de Lavras (UFLA).
ASTUDILLO, V.M. Fortalecimiento de la atención veterinaria y de los sistemas de información y vigilancia a nível local. Boletín del Centro Panamericano Fiebre Aftosa, n.57, p.77-84, 1991.
BRASIL. Ministério da Agricultura, Pecuária e Abastecimento. Decreto n. ${ }^{\circ}$ 5.741, de 30 de março de 2006. Diário Oficial da União, 31 mar. 2006. Seção 1, p.82, 2006a. 
BRASIL. Ministério da Agricultura, Pecuária e Abastecimento. Instrução normativa n. ${ }^{\circ} 17$, de 7 de abril de 2006. Diário Oficial da União, 10 abr. 2006. Seção 1, p.6, 2006b.

BRASIL. Ministério da Agricultura, Pecuária e Abastecimento. Instrução normativa n. ${ }^{\circ} 18$, de 18 de julho de 2006. Diário Oficial da União, 20 jul. 2006. Seção 1, p.6, 2006c.

BRASIL. Ministério da Agricultura, Pecuária e Abastecimento. Instrução normativa n. ${ }^{\circ} 32$, de 13 de maio de 2002 . Diário Oficial da União, 14 maio 2002. Seção 1, p.3, 2002.

BRASIL. Ministério da Agricultura, Pecuária e Abastecimento. Instrução normativa n. ${ }^{\circ}$ 44, de 23 de agosto de 2001. Diário Oficial da União, 24 ago. 2001. Seção 1, p.9, 2001.

BRASIL. Ministério da Agricultura, Pecuária e Abastecimento. Instrução normativa n. ${ }^{\circ} 78$, de 3 de novembro de 2003. Diário Oficial da União, 5 nov. 2003. Seção 1, p.3, 2003.

BRASIL. Ministério da Agricultura, Pecuária e Abastecimento. Lei n. ${ }^{\circ}$ 9.712, de 20 de novembro de 1998. Diário Oficial da União, 23 nov. 1998. Seção 1, p.1, 1998.

BRASIL. Ministério da Agricultura, Pecuária e Abastecimento. Portaria n. ${ }^{\circ}$ 50, de 19 de maio de 1997. Diário Oficial da União, 22 maio 1997. Seção 1, p.10.760, 1997.

BRASIL. Ministério da Agricultura, Pecuária e Abastecimento. Portaria n. 193, de 19 de setembro de 1994. Diário Oficial da União, 2 set. 1994. Seção 1, p.14309, 1994.

CARVALHO, L.F.R.; DE MELO, C.B.; HADDAD, J.P.A. Cadastro de exploração pecuária e controle do trânsito de bovídeos considerando a saúde animal no Brasil: uma breve revisão. Revista Brasileira de Medicina Veterinária, Rio de Janeiro, v.34, n. 1, p.19-26, 2012.

CHENG, H.W.; JEFFERSON, L. Different behavioral and physiological responses in two genetic lines of laying hens after transportation. Poultry Science, Oxford, v.87, n.5, p.885-892, 2008. DOI: 10.3382/ps.2007-00482.

DELEZIE, E.; SWENNEN, Q.; BUYSE, J.; DECUYPERE, E. The effect of feed withdrawal and crating density in transit on metabolism and meat quality of broilers at slaughter weight. Poultry Science, Oxford, v.86, n.7, p.1414-1423, 2007. DOI: 10.1093/ps/86.7.1414.

DENT, J.E.; KISS, I.Z.; ROWLAND, R.K.; ARNOLD, M. The potential spread of highly pathogenic avian influenza virus via dynamic contacts between poultry premises in Great Britain. BMC Veterinary Research, London, v.7, n.59, p.1-14, 2011 . DOI: 10.1186/1746-6148-7-59.

HARTUNG, J. The new E.U. Animal Transport Regulation: improved welfare and health or increased administration? Deutsche Tierärztliche Wochenschrift, Berlin, v.113, n.3, p.113-1 16, 2006.

MITCHELL, M.A.; KETTLEWELL, P.J. Engineering and design of vehicles for long distance road transport of livestock (ruminants, pigs and poultry). Veterinaria Italiana, Campo Boario, v.44, n. 1 , p.201-213, 2008.

NIJDAM, E.; ARENS, P.; LAMBOOIJ, E.; DECUYPERE, E.; STEGEMAN, J.A. Factors influencing bruises and mortality of broilers during catching, transport, and lairage. Poultry Science, Oxford, v.83, n.9, p.1610-1615, 2004.

RIBÒ, O.; CANDIANI, D.; AIASSA, E.; CORREIA, S.; AFONSO, A.; DE MASSIS, F.; SERRATOSA, J. Using scientific evidence to inform public policy on the long distance transportation of animals: role of the European Food Safety Authority. Veterinaria Italiana, Campo Boario, v.44, n. 1, p.87-94, 2008.

SERRÃO, U.M.; DORA, F.; MUZIO, F.; TAMAYO, H.; ASTUDILLO, V.M.; ZOTTELE, A. Atención veterinaria a nivel local. Boletín del Centro Panamericano de Fiebre Aftosa, n.57, p.60-66, 1991.

SILVA, R.B.T.R.; NAAS, I.A.; MOURA, D.J. Broiler and swine production: animal welfare legislation scenario. Scientia Agricola, Piracicaba, v.66, n.6, p.713-720, 2009. DOI: http://dx.doi. org/10.1590/SO103-90162009000600001.

UNIÃO BRASILEIRA DE AVICULTURA (Ubabef). Exportação mundial de carne de frango em 2012. 2012. Available from: <http://www. ubabef.com.br/estatisticas/frango/exportacao_mundial_carnefrango_2012>. Accessed on: 24 jul. 2013.

VAN STEENWINKEL, S.; RIBBENS, S.; DUCHEYNE, E; GOOSSENS, E.; DEWULF, J. Assessing biosecurity practices, movements and densities of poultry sites across Belgium, resulting in different farm risk-groups for infectious disease introduction and spread. Preventive Veterinary Medicine, Amsterdam, v.98, n.4, 259-270, 2011 . DOI: 10.1016/j.prevetmed.2010.12.004.

VECEREK, V.; GRBALOVA, S.; VOSLAROVA, E.; JANACKOVA, B.; MALENA, M. Effects of travel distance and the season of the year on death rates of broilers transported to poultry processing plants. Poultry Science, Oxford, v.85, n. 1 1, p.1881$1884,2006$. 